\title{
Determining the Bacteriological Pollution Level of Gelevera Creek, Giresun ${ }^{\text {*] }}$
}

\author{
Tamer AKKAN ${ }^{*} \quad$ Fatmagül ÇOLAKER ${ }^{2}$

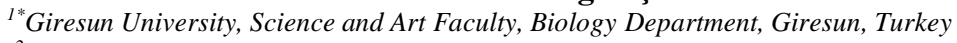 \\ ${ }^{2}$ Giresun University, Natural Sciences Institutes, Biology Division, Giresun, Turkey
}

How to cite: Akkan, T. \& Çolaker, F. (2020). Determining the Bacteriological Pollution Level of Gelevera Creek, Giresun. J. Anatolian Env. and Anim. Sciences, 5(4), 691-695.

Atıf yapmak için: Akkan, T. \& Çolaker, F. (2020). Gelevera Deresi (Giresun)'nin Bakteriyolojik Kirlilik Düzeyinin Belirlenmesi. J. Anadolu Çev. ve Hay. Dergisi, 5(4), 691-695.

: https://orcid.org/0000-0002-9866-4475 iD: https://orcid.org/0000-0002-8335-6584
*Corresponding author's:

Tamer AKKAN

Giresun University, Science and Art Faculty, Biology Department, Giresun, Turkey. $\varangle$ : biyoloji@yahoo.com

Mobile telephone: $+90(535) 3815210$

Telephone : $+90(454) 3101400$

Fax $\quad:+90(454) 3101477$
Abstract: The aim of this study is to investigate the bacteriological pollution level of Gelevera Creek (Giresun). For this purpose, a total of 48 water samples was collected from 4 different stations between April 2017-March 2018 and bacteriological parameters were analyzed using the standard methods. Bacteriologically, total count of bacteria at $37^{\circ} \mathrm{C}$ from water and sediment samples, and count of total coliform bacteria (TC), fecal coliform bacteria (FC), fecal streptococci (FS), E. coli from surface water samples were determined. The percentages for TC, FC and FS presence in surface water samples were $100 \%, 100 \%, 93.75 \%$ respectively. In addition, E. coli were determined in collected samples for almost all seasons. The levels of total coliform, fecal coliform and fecal streptococci exceeded the values recommended by World Health Organization (WHO) and values that are set according to Turkish standards. This issue is likely to cause serious and irreparable damage to the streamline. As a result, it was determined that surface water samples collected from Gelevera Creek are bacteriological polluted. Hence in this study, regular monitoring and assessment by using appropriate methods to reduce the bacterial load in the Gelevera Creek Basin are recommended.

Keywords: Gelevera creek, bacteriological pollution, water quality, E. coli.

\section{Gelevera Deresi (Giresun)’nin Bakteriyolojik Kirlilik Düzeyinin Belirlenmesi}

*Sorumlu yazarm: Tamer AKKAN

Giresun Üniversitesi, Fen Edebiyat Fakültesi, Biyoloji Bölümü, Giresun, Türkiye.

$\triangle$ : biyoloji@yahoo.com

Cep telefonu : $+90(535) 3815210$

Telefon : $+90(454) 3101400$

Faks $\quad:+90(454) 3101477$
Öz: Bu çalışmada Gelevera Deresi (Giresun)'nin bakteriyolojik kirlilik düzeyinin belirlenmesini amaçlamaktadır. Bu amaç için 4 farklı istasyondan toplam 48 su numunesi örneği Nisan 2017Mart 2018 tarihleri arasında toplanmış ve bakteriyolojik değişkenler standart metotlar kullanılarak analiz edilmiştir. Bakteriyolojik olarak su ve sediment örneklerinden $37^{\circ} \mathrm{C}$ 'deki toplam bakteri sayısı; yüzey suyu örneklerinden toplam koliform bakteri sayısı (TK), fekal koliform bakteri sayısı (FK), fekal streptokok bakteri sayısı (FS) ve E. coli sayısı belirlenmiştir. Yüzey suyu numunelerinde TK, FK ve FS bulunma yüzdeleri sırasıyla \%100, \%100, \%93,75’tir. Ayrıca, hemen hemen her mevsim için, toplanan örneklerde E. coli tespit edilmiştir. Toplam koliform, fekal koliform ve fekal streptokok bakteri seviyeleri, Dünya Sağlık Örgütü (DSÖ) tarafından önerilen değerleri ve Türk standartlarına göre belirlenen değerleri aşmaktadır. Bu durumun akarsu hattında ciddi ve onarılamaz hasara neden olması muhtemeldir. Sonuç olarak Gelevera Deresi yüzey suyu örneklerinin bakteriyolojik açıdan kirli olduğu belirlenmiştir. Dolayısıyla bu çalışmada Gelevera Deresi havzasındaki bakteriyel yükü azaltmak için uygun yöntemler kullanılarak düzenli izleme ve değerlendirme yapılması önerilmektedir.

$\underline{\text { Anahtar kelimeler: Gelevera deresi, bakteriyolojik kirlilik, su kalitesi, E. coli. }}$ 


\section{INTRODUCTION}

Epidemics necessitate the protection of usable water resources. Aquatic ecosystems are one of the most sensitive systems in terms of epidemics derived from bacteria and viruses that cause serious problems. Deterioration in bacteriological life in an aquatic environment adversely affects other living things that are highly organized and structured (Kalkan \& Altuğ, 2020). Therefore, bacteriological studies that carried out in these areas which have limited use are of great importance. In Turkey, there are many studies carried out for water quality of aquatic resources (Verep et al., 2019; Uncumusaoğlu \& Mutlu, 2017; Tokatlı et al., 2017; Mutlu et al., 2018; Uncumusaoğlu \& Mutlu, 2019; Güher \& Öterler, 2020; Gümüş \& Akköz, 2020; Balcıoglu, 2020). However, bacteriological studies are quite limited (Yalım et al., 2020; Altuğ et al., 2020; Akduman et al., 2020; Sönmez \& Sivri, 2020). Therefore, regular monitoring programs should ensure continuity in such studies, and information from a common database should be shared instantly.

This study deals with the present situation of bacteriological water quality in Gelevera Creek flowing into the Black Sea. Further, the data obtained as a result of this study will provide basic information about future planning for this freshwater resource.

\section{MATERIAL AND METHODS}

Study Area and Sampling: Gelevera Creek is located in Espiye of the Giresun province in Turkey. Similarly, it is also called as Özlüce Creek. It begins from the Balaban Mountains (Gümüşhane) and it is fed by many water supplies, especially Karadona Creek, Karaovacık Creek and Çukur Creek. The stream is $80 \mathrm{~km}$ in length. It lies along a narrow valley and flows into the Black Sea from Espiye the east of Giresun.

The surface water samples and sediment samples were collected from four stations (Figure 1) between April 2017 and March 2018 on a monthly basis for bacteriological analysis.

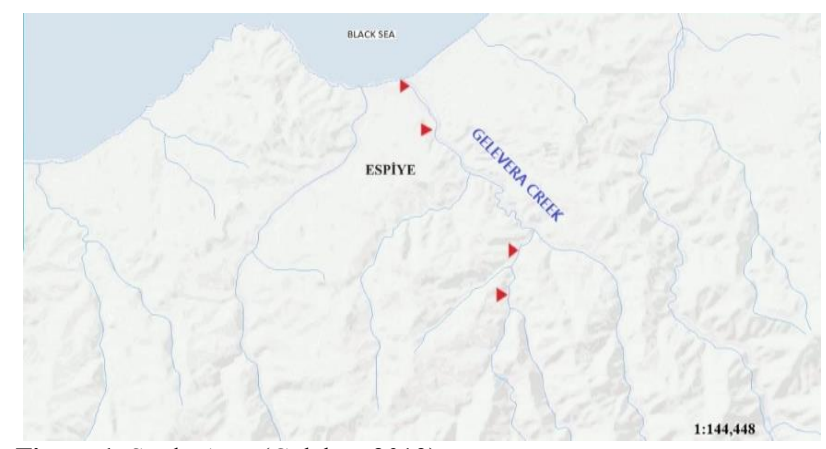

Figure 1. Study Area (Çolaker, 2019)
The surface water samples were then analyzed for total coliform $(T C)$, fecal coliform $(F C)$, fecal streptococcus $(F S)$, and $E$. coli. The sediment samples were also analyzed for total count of aerobic bacteria and total count of mesophilic aerobic bacteria. The most-probablenumber $(M P N)$ method was used for the $T C, F C$, and $F S$ count in order to determine the bacteriological quality. In addition, the standard plate count method was used in order to determine the bacteria count in both the sediment samples (homogenate rate 1:9) and water samples. Analyses were performed according to standard methodology (APHA, 1992).

\section{RESULTS AND DISCUSSION}

For surface water samples collected in summer, the count of $T C$ bacteria was $240->1100 M P N / 100 \mathrm{~mL}$, the count of $F C$ bacteria was $240->240 M P N / 100 \mathrm{~mL}$, and the count of $F S$ bacteria was 23-240> MPN/100 mL. The count of $E$. coli was determined to be between $15 \mathrm{cfu} / 100 \mathrm{~mL}$ and $203 \mathrm{cfu} / 100 \mathrm{~mL}$. Total viable bacteria count at $37^{\circ} \mathrm{C}$ ranged from $2.9 \times 10^{3}$ to $5.5 \times 10^{5} \mathrm{cfu} / \mathrm{mL}$ (Table 1 ).

For surface water samples collected in fall, the count of $T C$ bacteria was determined to be between 240$>1100 \mathrm{MPN} / 100 \mathrm{~mL}$, the count of $F C$ bacteria was 19 $>240 \mathrm{MPN} / 100 \mathrm{~mL}$, and the count of FS bacteria was 0240> MPN/100 mL. The count of $E$. coli varied between 0 $\mathrm{cfu} / 100 \mathrm{~mL}$ and $125 \mathrm{cfu} / 100 \mathrm{~mL}$. Total viable bacteria count at $37^{\circ} \mathrm{C}$ ranged from $8 \times 10^{2}$ to $1.5 \times 10^{4} \mathrm{cfu} / \mathrm{mL}$ (Table 1).

For surface water samples collected in winter, the count of $T C$ bacteria was determined to be between 23 $>1100 \mathrm{MPN} / 100 \mathrm{~mL}$, the count of $F C$ bacteria 9-240 $M P N / 100 \mathrm{~mL}$, and the count of $F S$ bacteria was between 23-240> MPN/100 mL. The count of E. coli was between 0 - $20 \mathrm{cfu} / 100 \mathrm{~mL}$. Total viable bacteria count at $37^{\circ} \mathrm{C}$ ranged from $1 \times 10^{2}$ to $1.3 \times 10^{3} \mathrm{cfu} / \mathrm{mL}$ (Table 1 ).

For surface water samples collected in spring, the bacterial counts in water samples were determined for $T C$ to be $90-1100 M P N / 100 \mathrm{~mL}$, for $F C$ to be $95->240$ $M P N / 100 \mathrm{~mL}$, for $F S$ to be 0-240 MPN/100 mL, and for $E$. coli to be between $10-50 \mathrm{cfu} / 100 \mathrm{~mL}$, respectively. Also, $37^{\circ} \mathrm{C}$, total viable bacteria count ranged from $2.4 \times 10^{2}$ to $6.6 \times 10^{3} \mathrm{cfu} / \mathrm{mL}$ (Table 1).

Total viable bacteria counts in sediment samples at $37^{\circ} \mathrm{C}$ were $32.5 \times 10^{3}-4.5 \times 10^{5} \mathrm{cfu} / 100 \mathrm{~mL}$ in summer; $1.3 \times 10^{4}-59 \times 10^{4} \mathrm{cfu} / 100 \mathrm{~mL}$ in fall, $9 \times 10^{1}-2.3 \times 10^{4}$ $\mathrm{cfu} / 100 \mathrm{~mL}$ in winter, and $3.7 \times 10^{4}-59.8 \times 10^{4} \mathrm{cfu} / 100 \mathrm{~mL}$ in spring. 
$\underline{\text { Table 1. Results of bacteria counts in surface water samples. }}$

\begin{tabular}{|c|c|c|c|c|c|c|c|c|c|c|}
\hline & \multirow{2}{*}{ Station } & \multicolumn{4}{|c|}{ Bacteria Count $(M P N / 100 \mathrm{~mL})$} & \multicolumn{5}{|c|}{ Bacteria Count (MPN/100 mL) } \\
\hline & & TC & FC & EC & FS & & TC & FC & EC & FS \\
\hline \multirow{3}{*}{ June } & 1 & 240 & 240 & 15 & 240 & \multirow{3}{*}{ December } & 93 & 9 & 0 & 23 \\
\hline & 2 & 460 & $>240$ & 17 & 240 & & 240 & 19 & 6 & 23 \\
\hline & 4 & $>1100$ & $>240$ & 37 & 240 & & 240 & 240 & 20 & 23 \\
\hline \multirow{4}{*}{ July } & 1 & 1100 & 240 & 103 & 23 & \multirow{4}{*}{ January } & 23 & 9 & 0 & 240 \\
\hline & 2 & $>1100$ & $>240$ & 23 & 23 & & 240 & 23 & 0 & $>240$ \\
\hline & 3 & 1100 & $>240$ & 37 & 23 & & 240 & 23 & 0 & 23 \\
\hline & 4 & $>1100$ & $>240$ & 135 & 23 & & $>1100$ & 240 & 20 & 240 \\
\hline \multirow{4}{*}{ August } & 1 & $>1100$ & $>240$ & 97 & $>240$ & \multirow{4}{*}{ February } & 23 & 9 & 0 & 23 \\
\hline & 2 & $>1100$ & $>240$ & 173 & $>240$ & & 23 & 23 & 0 & 240 \\
\hline & 3 & $>1100$ & $>240$ & 153 & 240 & & 23 & 95 & 0 & 23 \\
\hline & 4 & $>1100$ & $>240$ & 203 & 240 & & 240 & 95 & 0 & 23 \\
\hline \multirow{4}{*}{ September } & 1 & 460 & 240 & 7 & 0 & \multirow{4}{*}{ March } & 90 & 95 & 10 & 23 \\
\hline & 2 & 460 & $>240$ & 58 & 23 & & 460 & 240 & 10 & 23 \\
\hline & 3 & 460 & $>240$ & 70 & 240 & & 1100 & $>240$ & 20 & 23 \\
\hline & 4 & $>1100$ & $>240$ & 125 & 240 & & 1100 & $>240$ & 25 & 23 \\
\hline \multirow{3}{*}{ October } & 2 & 1100 & 95 & 51 & 23 & \multirow{3}{*}{ April } & 460 & 240 & 15 & 0 \\
\hline & 3 & 460 & 240 & 20 & $>240$ & & 240 & $>240$ & 25 & 95 \\
\hline & 4 & 1100 & $>240$ & 125 & 23 & & 1100 & $>240$ & 30 & 0 \\
\hline \multirow{4}{*}{ November } & 1 & 240 & 23 & 0 & 23 & \multirow{4}{*}{ May } & 240 & 240 & 20 & 240 \\
\hline & 2 & 460 & 95 & 75 & 23 & & 460 & $>240$ & 30 & 240 \\
\hline & 3 & 460 & 240 & 10 & 23 & & 460 & $>240$ & 35 & 23 \\
\hline & 4 & 460 & $>240$ & 120 & 23 & & 1100 & $>240$ & 50 & 23 \\
\hline
\end{tabular}

Eraslan Akkan et al. (2017) reported there was bacterial contamination at Harşit Stream and pointed out that bacteriological pollution had increased in summer and autumn, as well as that EC was detected at all sample stations. Aydin (2017) reported that percentages of TC, FC, EC and FS in the sixty surface water samples collected from Boğacık Creek were 98.33\%, 91.67\%, 83.33\% and $96.67 \%$ respectively. In a similar study conducted in Yağlidere Creek, the quality variables were detected as $45 \%$ for TC, as $71.66 \%$ for FC and $56.66 \%$ for FS (Akkan et al., 2019). In addition, the researchers pointed out that $E$. coli was present in the samples collected at any time of the year and the bacteriological flora was damaged. In this study, the percentages for TC, FC and FS presence in 48 surface water samples collected from Gelevera Creek were $100 \%, 100 \%$ and $93.75 \%$, respectively. E. coli was detected at high rates for almost all seasons at most sampling stations.

The abnormal crossing of reference ranges of at least one station each month paints a bleak picture for Gelevera Creek which is used for a variety of purposes such as drinking and irrigation. In particular, the density in the fecal origin bacterial population is much higher than the reference ranges, thus inviting a waterborne disease outbreak. The values obtained from this study are extremely high according to EPA and WHO standards (Table 2).

It was determined that the changes in the count of bacteria collected from the surface water samples at $37^{\circ} \mathrm{C}$ were between $2.9 \times 10^{3}$ and $5.5 \times 10^{5} \mathrm{kob} / \mathrm{mL}$ in summer; between $8 \times 10^{2}$ and $1.5 \times 10^{4} \mathrm{kob} / \mathrm{mL}$ in fall; between $1 \times 10^{2}$ and $1.3 \times 10^{3} \mathrm{kob} / \mathrm{mL}$ in winter; between $2.4 \times 10^{2}$ and 6.6 $\mathrm{x} 10^{3} \mathrm{kob} / \mathrm{mL}$ in spring. The changes in the count of bacteria collected from the sediment samples were determined to be between $32.5 \times 10^{3}$ and $4.5 \times 10^{5} \mathrm{kob} / \mathrm{mL}$ in summer; between $1.3 \times 10^{4}$ and $59 \times 10^{4} \mathrm{kob} / \mathrm{mL}$ in fall; between $9 \times 10^{1}$ and $2.3 \times 10^{4} \mathrm{kob} / \mathrm{mL}$ in winter; between $3.7 \times 10^{4}$ and $59.8 \times 10^{4}$ in spring. When the stations were examined, it has been reported that the largest to smallest order seasonally for count of bacteria at $37^{\circ} \mathrm{C}$ was summer, spring, fall, winter.

Table 2. Bacteriological Water Quality Parameters (Akkan et al., 2019).

\begin{tabular}{lcccc}
\hline Parameters & $\begin{array}{c}\text { RCWIHC, } \\
\mathbf{2 0 1 3}\end{array}$ & TS266 & $\begin{array}{c}\text { EPA, } \\
\mathbf{2 0 0 9}\end{array}$ & $\begin{array}{c}\text { WHO, } \\
\mathbf{2 0 1 7}\end{array}$ \\
\hline E. coli & $0 / 250 \mathrm{~mL}$ & $0 / 250 \mathrm{~mL}$ & 0 & 0 \\
FS & $0 / 250 \mathrm{~mL}$ & $0 / 250 \mathrm{~mL}$ & 0 & \\
TC & $0 / 250 \mathrm{~mL}$ & & 0 & 0 \\
FC & & & 0 & 0 \\
$22^{\circ} \mathrm{C}$ & $20 / \mathrm{mL}^{*}$ & $100 / \mathrm{mL}^{*}$ & & \\
$37^{\circ} \mathrm{C}$ & $5 / \mathrm{mL}^{*}$ & $20 / \mathrm{mL}^{*}$ & & \\
\hline * max. value & & &
\end{tabular}

According to findings of this study, it has been determined that pollution in surface water samples collected from Gelevera Creek was higher in sampling points corresponding to the district center and discharging area to the Black Sea. In addition, it has been observed that the stream load also carries additional pollutants to the area which coincides with the boundaries of Espiye district. When the results were analyzed, it was found that bacteriological pollution was higher in summer and spring than in fall and winter. 
When the literature and the results of this study were compared, it has been consolidated that as in many studies conducted throughout the country and global, bacteriological pollution in which sewage and domestic solid waste play a major role increases in warm seasons. Similarly, it has been consolidated that with the comparision of the studies conducted in Giresun and this study, additional organic load is discharging to the ecosystem of the Black Sea, and that this carries a high risk for the ecosystem. As a common point of these studies; it also has been found that in settlement centers affect the bacteriological pollution in streamlines directly.

\section{CONCLUSIONS}

In conclusion, it was determined that Gelevera Creek was bacteriologically contaminated. Detection of this condition in almost every month of the year and in most stations is a serious danger. Major reasons of this pollution are determined to be domestic waste and the waste of animal slaughterhouses, both of which are uncontrolled. It has been observed that the stream bed is exposed to domestic waste excessively and some industrial waste. Further, it was noted that uncontrolled destruction for anthropogenic reasons was carried out along the streamline.

It can be observed that current human population per unit area should be considered as an effect when the count of bacteria in streamline's water and sediment flora is examined. This is also another indication that the organic load upon the stream is excessive. Therefore, an outbreak of infectious waterborne diseases will unfortunately be inevitable if necessary, precautions are not taken by the local authorities.

\section{ACKNOWLEDGEMENTS}

This master thesis study was presented as a partially, in 1st international technological sciences and design symposium (ITESDES, 2018), 27-29 June 2018, Giresun-Turkey by poster presentation.

\section{REFERENCES}

Akduman, S., Demirbağ, M. \& Sivri, N. (2020). Türkiye'de bakteriyolojik su kalitesi konusunda yapılan bilimsel araştırmaların bibliyometrik analizi (1999-2019). Journal of Anatolian Environmental and Animal Sciences, 5(3), 425432.

Akkan, T., Mehel, S. \& Mutlu, C. (2019). Determining the level of bacteriological pollution level in
Yağlıdere Stream, Giresun. Journal of Limnology and Freshwater Fisheries Research, 5(2), 83-88.

Altuğ, G., Çardak, M., Çiftçi Türetken, P.S., Kalkan, S. \& Gürün, S. (2020). Antibiotic and heavy metal resistant bacteria isolated from Aegean Sea water and sediment in Güllük Bay, Turkey. Johnson Matthey Technology Review, 64(4), 507-525.

APHA. (1992). Standard methods for the examination of water and wastewater, 18th ed. Washington: APHA 9 p.

Aydın, A. (2017). Boğacık Deresi (Giresun)'nin bakteriyolojik yönden incelenmesi. Yüksek Lisans Tezi, Giresun Üniversitesi, Fen Bilimleri Enstitüsü, $37 \mathrm{~s}$.

Balcioglu, E. (2020). Determination and comparison of anionic surfactant and phosphate concentrations at the entrance and the exit of the Turkish Straits System (TSS). Marine Pollution Bulletin, 159, 111525.

Çolaker, F. (2019). Gelevera Deresi (Giresun) Bakteriyolojik Kirlilik Düzeyinin Belirlenmesi. Yüksek Lisans Tezi, Giresun Üniversitesi, Fen Bilimleri Enstitüsü, 50s.

EPA. (2009). United States Environmental Protection Agency. 2018 Edition of the Drinking Water Standards and Health Advisories Tables. March 2018.

Eraslan-Akkan, B. (2017). Harşit Çayı (Giresun)'nın Su Kalitesi ve Su Kirliliği Seviyesinin Belirlenmesi Üzerine Bir Araştırma. Doktora Tezi, Giresun Üniversitesi, Fen Bilimleri Enstitüsü, 107s.

Güher, H. \& Öterler, B. (2020). Seasonal change of physicochemical properties of Kayalıköy Reservoir (Kıklareli/Turkey) and determination of water quality. Journal of Limnology and Freshwater Fisheries Research, 6(2), 127-143.

Gümüş, N. \& Akköz, C. (2020). Eber Gölü (Afyonkarahisar) su kalitesinin araştırılması. Journal of Limnology and Freshwater Fisheries Research, 6(2), 153-163.

Kalkan, S. \& Altuğ, G. (2020). The composition of cultivable bacteria, bacterial pollution, and environmental variables of the coastal areas: an example from the Southeastern Black Sea, Turkey. Environmental Monitoring and Assessment, 192(6), 356.

Mutlu, C., Eraslan Akkan, B. \& Verep, B. (2018). The heavy metal assessment of Harsit Stream (Giresun, Turkey) using multivariate statistical techniques, Fresenius Environmental Bulletin, 27, 12B, 98519858.

RCWIHC. (2013). Regulation concerning water intended for human consumption. Ankara, Turkey: The Turkish Official Gazette. Report No.: 28580. 
Sönmez, V. \& Sivri, N. (2020). The toxic effects of commonly used antibiotics in turkey on aquatic organisms. Journal of Anatolian Environmental and Animal Sciences, 5(2), 154-160.

Tokatlı, C., Baştatlı, Y. \& Elipek, B. (2017). Water quality assessment of dam lakes located in Edirne province (Turkey). Sigma Journal of Engineering and Natural Sciences, 35(4), 743-750.

TS266. (2005). Water intended for human consumption. Ankara, Turkey: Turkish Standards Institute (TSE). Report No: 13.060.20.

Uncumusaoğlu, A.A. \& Mutlu, E. (2017). Determination of water quality and usability level of Eğlence Pond (Boyabat, Sinop). Alinteri Journal of Agricultural Sciences, 32(2), 25-37.

Uncumusaoğlu, A.A. \& Mutlu, E. (2019). Evaluating spatial and temporal variation in Tuzaklı Pond water using multivariate statistical analysis. Polish Journal of Environmental Studies, 28(5), 3861-3874.

Verep, B., Taşpınar Ölmez, B. \& Mutlu, C. (2019). Investigation of bacteriological and detergent-based pollution in the Salarha Basin Rivers. Journal of Anatolian Environmental and Animal Sciences, 4(3), 565-574.

WHO. (2017). Guidelines for Drinking-Water Quality, Fourth Edition. World Health Organization, NLM classification: WA 675, ISBN 978-92-4-154995-0.

Yalım, F., Emre, N., Gülle, İ., Emre, Y., Pak, F., Aktaş, Ö., Uysal, R. \& Veske, E . (2020). Karacaören I Baraj Gölü (Burdur) mikrobiyolojik kirlilik düzeyinin mevsimsel değişimi. Journal of Limnology and Freshwater Fisheries Research, 6(2), 120-126. 